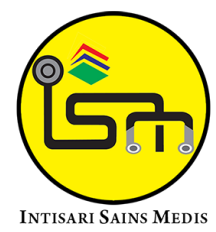

Published by Intisari Sains Medis

\title{
Peran sirkumsisi sebagai pencegahan infeksi herpes genetalis: suatu studi kohort retrospektif
}

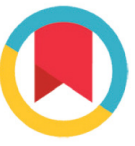

CrossMark

\author{
Made Wardhana ${ }^{1 *}$, Martina Windari ${ }^{1}$, Marrietta Sugiarti Sadeli ${ }^{1}$, \\ Anak Agung Gde Putra Wiraguna ${ }^{1}$, Ni Made Dwi Puspawati ${ }^{1}$, \\ I Gusti Ayu Agung Elis Indira' ${ }^{1}$ Pande Agung Mahariski ${ }^{1}$
}

'Departemen Dermatologi dan Venereologi, Fakultas Kedokteran Universitas Udayana/RSUP Sanglah, Denpasar, Bali, Indonesia
*Korespondensi:

Made Wardhana

Departemen Dermatologi dan Venereologi, Fakultas Kedokteran Universitas Udayana/RSUP Sanglah,

Denpasar, Bali, Indonesia;

made wardhana@yahoo.com

Diterima: 22-06-2021

Disetujui:11-08-2021

Diterbitkan: 25-08-2021

\section{ABSTRACT}

Background: Recurrent genital herpes (RGH) is a sexually transmitted infection that is a serious public health problem and is quite prominent in most countries worldwide. Management for this infection is antiviral and circumcision. Male circumcision significantly reduces human immunodeficiency virus (HIV) infection and other sexually transmitted infections. This research aims to evaluate circumcision efficacy as the prevention for herpes simplex virus type 2 (HSV-2) infection compared with oral acyclovir.

Methods: This research is an experimental study with a retrospective cohort approach. We included 45 males, 24 subjects circumcised and 21 subjects without circumcision and took oral acyclovir as standard treatment. RGH was diagnosed based on typical clinical manifestation. Follow up treatment every two weeks and continued to 2 months after circumcised and given with oral acyclovir. Successful treatment was stated without recurrent genital herpes.

Results: Of 24 circumcised subjects, 19 were cured, and five non-circumcised subjects suffered recurrent genital herpes (not cured). Among 21 subjects without circumcision was cured, and 12 subjects were not cured. Based on these results, the value of NNT=2.7.

Conclusion: Circumcision can be considered effective in reducing the incidence of $H G R$ and prevent recurrence of HGR with the NNT value of 2.7.
Keywords: Genital herpes, herpes simplex virus, recurrent herpes genitalis, sexually transmitted infections.

Cite This Article: Wardhana, M., Windari, M., Sadeli, M.S., Wiraguna, A.A.G.P., Puspawati, N.M.D., Indira, I.G.A.A.E., Mahariski, P.A. 2021. Peran sirkumsisi sebagai pencegahan infeksi herpes genetalis: suatu studi kohort retrospektif. Intisari Sains Medis 12(2): 597-600. D0l: 10.15562/ism.v12i2.1069

\section{ABSTRAK}

Latar Belakang: Herpes genetalis rekuren (HGR) merupakan infeksi menular seksual menjadi masalah kesehatan masyarakat yang serius dan cukup menonjol pada sebagian besar negara di dunia. Penanganannya adalah oral dengan antivirus dan tindakan sirkumsisi. Sirkumsisi pada pria secara signifikan mengurangi insiden infeksi human immunodeficiency virus (HIV) dan penyakit infeksi menular lainnya. Penelitian ini mengevaluasi efikasi sirkumsisi sebagai pencegahan infeksi virus herpes simpleks tipe 2 (HSV-2) dibandingkan dengan pemberian obat asiklovir.

Metode: Studi ekperimental dengan pendekatan retrospektif kohort dengan mengikutsertakan 45 subjek pria dewasa, 24 subjek disirkumsisi dan 21 tanpa sirkumsisi dan hanya diberikan asiklovir sebagai obat standar. Diagnosis HGR dilakukan secara klinis dengan yang manifestasi klinis yang khas da pemeriksaan Tzanck. Setelah pemberian terapi dilakukan kontrol setiap 2 minggu sampai 2 bulan. Terapi dinyatakan berhasil bila tidak ada kekambuhan.

Hasil: Dari 24 subjek disirkumsisi, 19 subjek dinyatakan sembuh dan 5 subjek mengalami kekambuhan (tidak sembuh). Dari 21 subjek tanpa sirkumsisi, 9 subjek dinyatakan sembuh dan 12 subjek dinyatakan tidak sembuh. Berdasarkan hasil ini didapatkan nilai NNT $=2,7$.

Simpulan: Sirkumsisi dapat dinilai cukup efektif mengurangi angka kejadian HGR dan dapat mencegah kekambuhan HGR dengan nilai NNT 2.7.
Kata kunci: Herpes genital, herpes simplex virus, herpes genitalis rekuren, infeksi menular seksual.

Cite This Article:Wardhana, M., Windari, M., Sadeli, M.S., Wiraguna, A.A.G.P., Puspawati, N.M.D., Indira, I.G.A.A.E., Mahariski, P.A. 2021. Peran sirkumsisi sebagai pencegahan infeksi herpes genetalis: suatu studi kohort retrospektif. Intisari Sains Medis 12(2): 597-600. D0I: 10.15562/ism.v12i2.1069 


\section{PENDAHULUAN}

Herpes genetalis rekuren (HGR) merupakan infeksi menular seksual menjadi masalah kesehatan masyarakat yang serius dan cukup menonjol pada sebagian besar negara didunia. Prevalensi kasus ini di berbagai negara tidak diketahui dengan pasti, namun berdasarkan laporan oleh WHO (World Health Organization) terdapat sekitar 250 juta penderita baru dengan diagnosis gonorrhea, sifilis, dan herpes genitalis yang menurut hasil analisis jumlah tersebut cenderung meningkat dari waktu ke waktu. Data WHO diperkirakan usia 15-49 tahun yang hidup dengan infeksi HSV-2 di seluruh dunia pada tahun 2003 sejumlah 536 juta jiwa. Wanita lebih banyak yang terinfeksi dibanding pria, dengan perkiraan 315 juta kasus. ${ }^{1,2}$

Penyakit ini disebabkan herpes simplex virus (HSV) terutama tipe 2. Gejala klinis herpes simpleks genitalis khas berupa vesikel berkelompok, diatas dasar eritematosa, umumnya bersifat rekuren. Penyakit ini penyebab utama ulserasi genital, biasanya terdapat di preputium bagian luar maupun bagian dalam, sulkus koronarius, gland penis, dan penile shaft bagian distal. Penyakit ini jarang terjadi pada pangkal penis, inguinal, dan skrotum. Ada banyak faktor risiko sebagai pencetus panyakit ini seperti stres, kelelahan fisik, menurunnya kekebalan tubuh, obatobatan preputium yang panjang (tidak disirkumsisi), dan lain sebagainya. ${ }^{3,4}$

Penegakan diagnosis penyakit ini dapat dilakukan melalui anamnesis, pemeriksaan fisik, dan pemeriksaan laboratorium. Pemeriksaan yang khas berupa vesikel bergerombol di atas kulit yang eritematosa. Tes Tzanck dapat digunakan untuk mengonfirmasi diagnosis. Pemeriksaan sitologi infeksi herpes adalah berupa sel akantolitik dan sel datia berinti banyak (multinucleated giant cell). ${ }^{3}$

Sirkumsisi adalah tindakan operatif yang bertujuan untuk mengangkat Sebagian maupun seluruh bagian dari prepusium penis sehingga keseluruhan glans penis dan corona radiata terlihat jelas. Sirkumsisi termasuk dalam prosedur bedah minor, dengan anestesi infiltrasi, biasanya sering dihubungkan dengan keagamaan. Dari sisi medis, manfaat sirkumsisi yaitu dapat mengurangi risiko infeksi penyakit seksual menular seperti human papilloma virus (HPV), herpes genetalis, sifilis, mencegah terjadinya penyakit pada pada gland penis atau prepusium seperti liken sklerosus (dapat menyebabkan kanker penis teruama pada usia lanjut).,

Banyak penelitian yang menyatakan bahwa sirkumsisi secara signifikan mengurangi kejadian infeksi HIV, HSV tipe 2, HPV, dan sifilis pada remaja. Demikian juga sebuah penelitian pada 477 pasien yang disirkumsisi, memberikan efek kesembuhan/tidak mengalami kekambuhan terhadap infeksi HPV dibandingkan dengan pasien yang tidak disirkumsisi. ${ }^{3,6,7}$

Banyak penelitian eksperimental merekomendasikan sirkumsisi sebagai salah satu upaya pencegahan penularan HGR yang secara signifikan menurunkan kejadian infeksi HPV. Penelitian ini mengevaluasi efikasi sirkumsisi sebagai pencegahan infeksi HSV-2 dibandingkan dengan pemberian obat asiklovir.

\section{METODE PENELITIAN}

Untuk menilai peran sirkumsisi sebagai pencegahan HGR dilakukan studi eksperimental dengan pendekatan kohort retrospektif pada tahun 2015-2018 di Poliklinik Kulit dan Kelamin RSUP Sanglah, Denpasar. Penelitian ini telah mendapatkan nomor keterangan kelaikan etik yaitu 1373/UN.14.2/Litbang/2015. Pasien herpes genitalis didiagnosis secara klinis dan tes Tzanck. Pasien yang disirkumsisi atas permintaan sendiri oleh karena terjadinya infeksi herpes genital berulang. Penelitian dibagi ke dalam 2 kelompok yaitu kelompok dengan sirkumsisi dan kelompok tanpa sirkumsisi dan hanya diberikan terapi asiklovir oral dengan dosis $200 \mathrm{mg}$ setiap 4,5 jam selama 7 hari. Follow-up dilakukan pada 2 minggu pertama dan 1 bulan setelah dilakukan sirkumsisi dan diberikan asiklovir. Keberhasilan terapi dinyatakan bila tidak mengalami kekambuhan herpes genitalis selama penelitian berlangsung.

Analisa hasil penelitian dengan SPSS 20 dan prinsip epidemiologi klinis dengan menganalisa menggunakan tabel $2 \times 2$ dengan keterangan: a. pasien yang disirkumsisi dan tidak mengalami kekambuhan (dikategorikan sembuh); b. pasien yang dilakukan sirkumsisi dan mengalami kekambuhan (dikategorikan gagal/tidak sembuh); c. pasien yang tidak sirkumsisi dan mengalami kesembuhan; dan d. pasien yang tidak disirkumsisi dan mengalami kekambuhan atau tidak sembuh.

\section{HASIL PENELITIAN}

Penelitian ini merekrut 41 subjek dengan herpes genitalis yang terdiri dari 23 subjek dilakukan sirkumsisi dan 18 tidak disirkumsisi. Karakteristik subjek penelitian dapat dilihat pada Tabel 1 .

Dari Tabel 1 dimasukan kedalam tabel $2 \times 2$, maka kita dapat menghitung $\mathrm{CER}=$ $\mathrm{a} /(\mathrm{a}+\mathrm{b})=12 / 21=0,57$ adalah kegagalan pada kelompok yang tidak disirkumsisi (control event rate), experimental event rate (EER) adalah kegagalan jadian pada kelompok sirkumsisi $=c /(c+d)=$ $5 / 24=0,20$. Relative risk reduction (RRR) menunjukkan berapa persen tindakan sirkumsisi dapat menurunkan kegagalan terapi, dihitung dengan rumusRRR $=(\mathrm{CER}-$ EER)/CER. Absolute risk reduction (ARR) menunjukkan perbedaan kegagalan aktual antara kelompok sirkumsisi dan kelompok tidak disirkumsisi. ARR dihitung dengan menggunakan rumus $\mathrm{ARR}=\mathrm{CER}-\mathrm{EER}=0,37 . \mathrm{NNT}$ (number needed to treat) menunjukkan jumlah pasien yang harus disirkumsisi untuk memperoleh tambahan 1 hasil yang baik atau kesembuhan. NNT $=1 / \mathrm{ARR}=$ $1 / 0,37=2,7$. Hal ini berarti kita melakukan 2-3 sirkumsisi untuk mendapatkan 1 kesembuhan, nilai ini cukup efektif.

\section{DISKUSI}

Pada penelitian ini didapatkan 45 pasien dengan herpes genetalis rekuren, 24 disirkumsisi atas permintaan sendiri dan 21 tidak disirkumsisi serta hanya diberikan pengobatan oral dengan Asiklovir sesuai standar. Lokasi terbanyak pada prepusium, gland penis dan korona penis. Teori mengatakan prepusium yang sempit merupakan faktor risiko terjadinya infeksi HPV.

Berdasarkan Tabel 1, subjek yang disirkumsi yaitu 19 (42,2 \%) dinyatakan sembuh, subjek yang tidak disirkumsisi yaitu $9(20,0 \%)$ dinyatakan sembuh dan 
Tabel 1. Karakteristik Subjek Penelitian

\begin{tabular}{|c|c|c|c|c|}
\hline \multirow{2}{*}{ Karakteristik } & \multicolumn{2}{|c|}{$\begin{array}{c}\text { Sirkumsisi } \\
n=24(53,3 \%)\end{array}$} & \multicolumn{2}{|c|}{$\begin{array}{c}\text { Tidak disirkumsisi } \\
n=21(46,7 \%)\end{array}$} \\
\hline & $\begin{array}{l}\text { Sembuh } \\
19(42,2)\end{array}$ & $\begin{array}{c}\text { Kambuh } \\
5(11,1)\end{array}$ & $\begin{array}{c}\text { Sembuh } \\
9(20,0)\end{array}$ & $\begin{array}{l}\text { Kambuh } \\
12(26,7)\end{array}$ \\
\hline \multicolumn{5}{|l|}{ Lokasi } \\
\hline Prepusium & 8 & 3 & 2 & 3 \\
\hline Gland penis & 2 & 1 & 2 & 2 \\
\hline Sulkus koronarius & 1 & 2 & 3 & - \\
\hline Shaft penis & 3 & 3 & - & 1 \\
\hline Skrotum & & - & 1 & - \\
\hline \multicolumn{5}{|l|}{ Frekuensi kekambuhan } \\
\hline 1-2 kali & 9 & 5 & 8 & 4 \\
\hline$>2$ kali & 5 & 4 & 5 & 2 \\
\hline \multicolumn{5}{|l|}{ Merokok } \\
\hline Ya & 8 & 4 & 9 & 5 \\
\hline Tidak & 6 & 5 & 4 & 1 \\
\hline \multicolumn{5}{|l|}{ Konsumsi alkohol } \\
\hline Ya & 9 & 4 & 8 & 4 \\
\hline Tidak & 5 & 5 & 5 & 2 \\
\hline \multicolumn{5}{|l|}{ Kelelahan fisik } \\
\hline Ya & 9 & 6 & 9 & 3 \\
\hline Tidak & 5 & 3 & 4 & 3 \\
\hline \multicolumn{5}{|l|}{ Stres psikologis } \\
\hline Ya & 8 & 5 & 10 & 5 \\
\hline Tidak & 6 & 4 & 3 & 1 \\
\hline
\end{tabular}

secara statistik signifikan. Hal yang sama juga dilaporkan oleh penelitian Mehtaa dkk. tahun 2012 pada uji eksperimental di Afrika Selatan dan Uganda bahwa sirkumsisi memiliki $62 \%$ potensi protektif terhadap HPV dan penurunan prevalensi HSV-2 serta ulkus genital. Menentukan penyebab ulkus genital diperlukan untuk mengurangi risiko terkait HIV dan untuk memahami bagaimana sunat memberikan perlindungan terhadap HIV. Pada kelompok sirkumsisi terjadi 69\% HGR dan tanpa sirkumsisi terjadi 83\% HGR.

Jerath dkk. tahun 2009 melakukan 21 penelitian studi multisenter dengan melakukan sirkumsisi sebanyak 8.046 pasien dan 6.336 pasien yang tidak disirkumsisi dan melakukan metaanalisis. Sirkumsisi berhubungan dengan insidensi HPV genital secara signifikan dan secara statistik prevalensi berkurang 0,57 (95\% CI (confidence interval): 0,42-0,77). Dari studi meta-analisis ini berkesimpulan bahwa hubungan antara prevalensi HPV genital pada pria dan efek sirkumsisi terapeutik untuk mencegah kekambuhan herpes genitalis. Tindakan ini menyebabkan penis menjadi tidak lembab. Penelitian ini mempergunakan dua puluh pasien dengan riwayat herpes genetalis berulang dilakukan sirkumsisi. Dua puluh lebih pria dewasa mengalami herpes genitalis berulang dan selama periode yang sama dipilih sebagai kontrol/ tidak disirkumsisi. Semua pasien dan kontrol ditindaklanjuti kekambuhan herpes genitalis. Tujuh pasien melaporkan tidak ada kekambuhan selama 3-18 tahun, tujuh pasien mengalami dua sampai enam tindak disirkumsisi, rekurensi per orang per tahun dibandingkan dengan rekurensi 0,20 (rata-rata) per orang per tahun dicatat sebelum sirkumsisi. Dua pasien memiliki kekambuhan pertama 11 tahun setelah sirkumsisi. Sebagai perbandingan, 14 kontrol memiliki 0,17 (rata-rata) rekurensi per orang per tahun, sebanding dengan jumlah kekambuhan pada pasien yang tidak disirkumsisi dan sering pada interval yang lebih pendek. Meskipun penelitian kecil, sirkumsisi tampaknya mengurangi jumlah kekambuhan ratarata dan terbukti memperpanjang periode bebas penyakit diantara dua pengulangan. ${ }^{5,8,9}$ kekambuhan selama 11-27 tahun setelah
Gray dkk tahun 2009 melakukan uji ekperimen secara acak menunjukkan bahwa pada pasien yang disirkumsisi mengurangi kejadian HIV, HSV-2, dan penyakit ulkus genital simptomatik dalam dua uji coba acak di Uganda. Gejala ulkus genetalis, status HSV-2, dan penularan HIV ditentukan pada saat pengamatan pada 6, 12, dan 24 bulan. Pada pria yang disirkumsisi dibandingkan yang tidak disirkumsisi dan menilai efek HSV-2 serostatus sebagai pemodifikasi risiko. Penelitian ini memperkirakan proporsi efek pada penularan HIV yang dimediasi oleh gejala ulkus genetalis dan oleh infeksi HSV-2. Sirkumsisi secara signifikan mengurangi ulkus genitalis dan pada serokonversi HSV-2. Proporsiulkus genital karena HSV-2 terdeteksi oleh PCR adalah $48,0 \%$ pada pria yang disirkumsisi dan $39,3 \%$ pada pria yang tidak disirkumsisi. Sirkumsisi mengurangi risiko penularan HIV pada pria seronegatif HSV-2, rasio tingkat kejadian odd ratio $=0,34(95 \%$ CI: 0,15-0,81). Proporsi penurunan HIV akuisisi pada laki-laki yang disirkumsisi dimediasi oleh pengurangan ulkus genital simtomatik adalah $11,2 \%$ (95\% CI: 50 $38,0)$. Sirkumsisi pada remaja pria dan pria dewasa di populasi pedesaan Uganda secara signifikan mengurangi kejadian infeksi HSV-2 dan prevalensi infeksi HPV selama 24 bulan follow-up namun tidak berpengaruh pada kejadian sifilis. Efikasi sirkumsisi untuk pencegahan kejadian HSV-2. Hasil penyesuaian di peningkatan secara sederhana pada efikasi mencapai $28 \%$ pada infeksi HSV-2 namun tidak mengubah efikasi untuk infeksi HPV. Penemuan ini sesuai dengan penelitian observasional, yang mengurangi tingkat infeksi HSV-2 dan HPV yang berhubungan dengan sirkumsisi, penemuan ini sesuai dengan uji klinis sebelumnya, mengindikasikan bahwa sirkumsisi seharusnya dapat diterima sebagai langkah intervensi yang ampuh untuk mengurangi infeksi dengan HSV-2, HPV, dan HIV pada remaja pria dan pria dewasa. ${ }^{5,10}$

Macon pada tahun 2013 dengan hasil dari dua RCT menunjukkan sirkumsisi menjadi intervensi yang efektif untuk pencegahan HSV-2. Karena satu percobaan tidak mencapai signifikansi statistik, hasil keseluruhan 
tidak meyakinkan. Untuk meningkatkan penelitian lebih lanjut, populasi usia dan geografis yang lebih besar harus direkrut. ${ }^{11}$

Weiss dkk tahun 2006 menyatakan sirkumsisi secara signifikan mengurangi kejadian infeksi HIV di antara lakilaki dalam tiga uji klinis. Penelitian ini menilai kemanjuran sirkumsisi laki-laki untuk pencegahan HSV-2, infeksi HPV, dan sifilis pada remaja laki-laki yang HIV-negatif dan laki-laki dengan rongga subprepusium yang lembab dapat menjadi lingkungan yang menguntungkan untuk HSV-2 dan HPV dapat bertahan hidup dan sebagai hasilnya terjadilah infeksi pada epitel. ${ }^{12-14}$ Kedua replikasi HVS2 dan HPV di sel epitel epidermis dan dermis, dan bagian dalam mukosa kulup dengan mudah berkeratin, yang dapat memfasilitasi akses HSV-2 dan HPV ke bagian bawah sel epitel pada remaja pria dan pria dewasa yang tidak disirkumsisi. Setelah sirkumsisi dan keratinisasi skar pembedahan, resiko seperti infeksi epitel mungkin berkurang. ${ }^{12}$

Grund pada tahun 2017 dalam metaanalisis dengan pencarian publikasi melaporkan hubungan antara sirkumsisi pada pria dan hasil kesehatan wanita di sub-Sahara Afrika. Semua hasil biomedis di semua jenis studi dimasukkan. Temuan 60 publikasi dimasukkan dalam penilaian. Bukti konsistensi tinggi ditemukan untuk lima hasil dengan sunat pada pria melindungi dari kanker serviks, displasia serviks, virus HSV-2, klamidia, dan sifilis. Hal ini membuktikan untuk sirkumsisi pada pria dapat melindungi dari HPV risiko rendah. ${ }^{15}$

Sirkumsisi saat ini menunjukkan penurunan tingkat infeksi pada pria dan mengurangi beberapa infeksi infeksi HIV dan infeksi menular seksual pada kedua jenis kelamin serta keuntungan ini seharusnya membimbing kebijakan kesehatan masyarakat untuk program sirkumsisi pada neonatal, remaja, dan pria dewasa.

\section{SIMPULAN}

Sirkumsisi dapat mencegah kekambuhan HGR, terutama pada prepusium dengan NNT sebesar 2,7. Hal ini artinya kita memerlukan sirkumsisi antara 2-3 pasien untuk memndapatkan satu kesembuhan. Makin kecil NNT semakin baik. Menurut literatur NNT antara 1-5 sudah dikatakan baik.

\section{KONFLIK KEPENTINGAN}

Penulis menyatakan tidak ada konflik kepentingan terkait publikasi ini.

\section{PENDANAAN}

Tidak ada pendanaan.

\section{KONTRIBUSI PENULIS}

Penulis MW berkontribusi terhadap ide, pelaksanaan, dan koordinator penelitian serta penyusunan manuskrip dan pencarian referensi. Penulis AAGP dan IGAAEI bertanggung jawab terhadap pelaksanaan penelitian. Penulis MW, MSS, dan PAM bertanggung jawab terhadap penyusunan manuskrip.

\section{REFERENSI}

1. Groves MJ. Genital herpes: a review. Am Fam Physician. 2016;93(11):928-34.

2. Patel R, Kennedy OJ, Clarke E, Geretti A, Nilsen A, Lautenschlager S, et al. 2017 European guidelines for the management of genital herpes. Int J STD AIDS. 2017;28(14):1366-79.

3. Sauerbrei A. Herpes Genitalis: Diagnosis, Treatment and Prevention. Geburtshilfe Frauenheilkd. 2016;76(12):1310-7.

4. Mehta SD, Moses S, Parker CB, Agot K, Maclean I, Bailey RC. Circumcision status and incident herpes simplex virus type 2 infection, genital ulcer disease, and HIV infection. AIDS. 2012;26(9):1141-9.
5. Gray RH, Kigozi G, Serwadda D, Makumbi F, Watya S, Nalugoda F, et al. Male circumcision for HIV prevention in men in Rakai, Uganda: a randomised trial. Lancet. 2007;369(9562):65766.

6. Tobian AAR, Serwadda D, Quinn TC, Kigozi G, Gravitt PE, Laeyendecker O, et al. Male Circumcision for the Prevention of HSV-2 and HPV Infections and Syphilis. N Engl J Med. 2009;360(13):1298-309.

7. Van Howe RS. Sexually Transmitted Infections and Male Circumcision: A Systematic Review and Meta-Analysis. ISRN Urol. 2013;2013:142.

8. Jerath VP, Mahajan VK. Does circumcision influence recurrences in herpes genitalis? Indian J Dermatol Venereol Leprol. 2009;75(6):575-8.

9. Joelle ST, Taljaard D, Lissouba P, Zarca K, Puren A, Lagarde E, et al. Effect of HSV-2 serostatus on acquisition of HIV by young men: Results of a longitudinal study in orange farm, South Africa. J Infect Dis. 2009;199(7):958-64.

10. Gray RH, Serwadda D, Tobian AAR, Chen MZ, Makumbi F, Suntoke T, et al. Effects of genital ulcer disease and herpes simplex virus type 2 on the efficacy of male circumcision for HIV prevention: Analyses from the Rakai trials. PLoS Med. 2009;6(11):1-8.

11. Macon MK. Does Male Circumcision Prevent Herpes Simplex Virus Type 2 in Sexually Active Males Aged 18-50? PCOM Physician Assist Stud Student Scholarsh. 2014;(173):1-15.

12. Weiss HA, Thomas SL, Munabi SK, Hayes RJ. Male circumcision and risk of syphilis, chancroid, and genital herpes: a systematic review and meta-analysis. Sex Transm Infect. 2006;82(2):101-9.

13. Luis $\mathrm{H}$, Fridayantara WD, Mahariski P, Wignall FS, Irwanto I, Gedela K. Evolving ART crisis for people living with HIV in Indonesia. Lancet HIV. 2020;7(6):e384-5.

14. Somia IKA, Merati TP, Sukmawati DD, Indira IGAAE, Dwija IBNP, Prasetia MYO, et al. Prevalence of and risk factors associated with anal HPV infection among men who have sex with men in Bali, Indonesia. Bali Med J. 2020;9(3):646-53.

15. Grund JM, Bryant TS, Jackson I, Curran K, Bock N, Toledo C, et al. Association between male circumcision and women's biomedical health outcomes: a systematic review. Lancet Glob Heal. 2017;5(11):e1113-22.

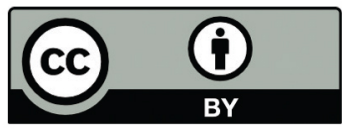

This work is licensed under a Creative Commons Attribution 